Georgetown University Law Center Scholarship @ GEORGETOWN LAW

\title{
No Longer a Privileged Few: Expense Claims, Prosecution and Parliamentary Privilege
}

Yvonne Tew

Georgetown University Law Center, ymt8@georgetown.edu

This paper can be downloaded free of charge from:

https://scholarship.law.georgetown.edu/facpub/1925

70 Cambridge L.J. 282-284 (2011)

This open-access article is brought to you by the Georgetown Law Library. Posted with permission of the author. Follow this and additional works at: https://scholarship.law.georgetown.edu/facpub

Part of the Criminal Law Commons, and the European Law Commons 
to any amending legislation which may be introduced. The political reality is that the Government is reluctant to introduce any amending legislation. Were it to do so, challenges are particularly likely if its legislative proposals fall short of Frodl's interpretation of Hirst: the six month timetable may merely have postponed the need to clarify the Convention's requirements.

SOPHIE BRIANT

\section{NO LONGER A PRIVILEGED FEW: EXPENSE CLAIMS, PROSECUTION AND PARLIAMENTARY PRIVILEGE}

THE publication of the expenses claims of Members of Parliament by the Daily Telegraph in 2009 revealed false claims made by MPs for costs incurred in the performance of their Parliamentary duties. David Chaytor, James Devine, and Elliot Morley, three MPs, were subsequently charged with false accounting, under section 17(1)(b) of the Theft Act 1968, for claiming non-existent expenses. The MPs argued that the criminal courts did not have jurisdiction to try their cases because they were protected by parliamentary privilege. This contention was rejected in the Crown Court and the Court of Appeal. The Lord Chief Justice, giving judgment for the Court of Appeal ( $R$ v. Chaytor (and others) [2010] EWCA Crim 1910), concluded "parliamentary privilege... has never ever attached to ordinary criminal activities by members of Parliament" (at [81]).

The Supreme Court in $R$ v. Chaytor (and others) [2010] UKSC 52, [2010] 3 W.L.R. 1707 unanimously decided that expense claims are not protected by parliamentary privilege within the meaning of article 9 of the Bill of Rights 1689, nor are they a matter within the exclusive jurisdiction of Parliament. The Supreme Court's decision clarifies several issues. First, the Supreme Court was clear that the issue in question was whether parliamentary privilege attached to the claiming of MPs expenses - a question that must be determined independently of whether or not such claims were dishonest (at [25]). It was inappropriate for the Court of Appeal to have examined the question on the premise that the claims were dishonest as "[p]rivilege from criminal prosecution would be nugatory if it did not apply to criminal conduct" (at [24]).

Second, the court distinguished between two bases of parliamentary privilege (at [12]-[13]). The first originates from article 9 of the Bill of Rights, which provides that "freedom of speech and debates" or "proceedings in Parliament" cannot be questioned in court. In the leading judgment, Lord Phillips clarified that whether a matter can be 
considered to fall within "proceedings in Parliament" must relate to how closely it impacts on the "core or essential business of Parliament" protected by article 9, which is "directed [at] freedom of speech and debate in the Houses at Parliament" (at [47]). Submitting expense claim forms does not qualify as "proceedings in Parliament" as judicial scrutiny of such claims would not inhibit debate in Parliament or affect its core business (at [48]). This requirement for a close nexus to the article's objective must be right. Article 9 should be narrowly construed to ensure that all claims to privilege are tested in light of its important purpose: to protect the MPs' freedom to debate in Parliament without interference. This freedom as envisaged by the Bill of Rights is so fundamental that privilege under article 9 is absolute; it is incapable of waiver even by Parliament (at [25]).

The second base of privilege examined by the Supreme Court relates to the matters under the exclusive cognizance of Parliament. The doctrine that Parliament has an exclusive right to manage certain affairs is wider than that under article 9, but the right is not absolute and may be waived. Would submission of expense claims fall within the exclusive jurisdiction of Parliament? The court held not. Making claims for parliamentary allowances is an administrative activity; the court agreed with the Joint Committee on Parliamentary Privilege Report (1998-99) (at 247-8) that only in "exceptional" circumstances were management functions so closely and directly connected to parliamentary proceedings that judicial intervention intruded on Parliament's sovereignty. Parliament has, through legislation - the Parliamentary Corporate Bodies Act 1992 which allows actions in contract and tort to be brought by and against the House-and administrative changes, relinquished any claim of exclusive cognizance in relation to administrative business of the two Houses (at [72], [74] and [89]). Further, as in previous criminal proceedings, Parliament had cooperated with the police investigation of the expense scandal - an indication that it did not wish to assert exclusive jurisdiction over the issue (at [90]-[91]). Parliament may also take disciplinary measures against criminal conduct that amounts to contempt of Parliament, but this does not exclude the courts' "different, but overlapping, jurisdiction" (at [81]).

Third, the comments made by the Court are indicative of the approach of the court towards narrowly construing the scope of parliamentary privilege. While Lord Phillips considered the two bases of parliamentary privilege separately, Lord Rodger, in his concurring opinion, reasoned that unless the matter was within the exclusive cognizance of Parliament, article 9 could not itself confer privilege. As such, "...there is only one basic question": whether the matter falls within Parliament's exclusive jurisdiction (at [102]-[104]). But collapsing both bases into one question in this way obscures the distinction 
between protection based on article 9 and the exclusive cognizance of Parliament. Lord Phillips' approach is preferable because it recognises that freedom of speech and debate lie at the very heart of what privilege aims to protect. These issues are afforded absolute protection under article 9 and may overlap with, but are distinct from, issues that fall under the exclusive cognizance of Parliament.

The unanimous decision of the nine Justices is an unsurprising development, given the way that judicial scrutiny of parliamentary privilege has evolved. Judicial and parliamentary views have moved from a Blackstonian absolutist concept of privilege towards a democratic model (see J. Chafetz, Democracy's Privileged Few (2007)) - a movement in parallel with increasing challenges to the doctrine of undiluted parliamentary sovereignty. The enactment of the Parliamentary Standards Act 2009 to regulate MP allowances and the Bribery Act 2010, which applies equally to parliamentarians, further illustrate the changing perceptions regarding the immunity of democratic representatives. Privilege no longer appears "to dazzle lawyers and judges outside Parliament" (at [101]). The scope of privilege is increasingly being narrowed to avoid it being used for reasons unrelated to those functions considered essential to an MP's democratic duties, central to which is the ability to debate openly and fearlessly in Parliament. Following the Supreme Court's decision that privilege did not pose any bar to prosecution of the MPs, David Chaytor pleaded guilty and was sentenced in the Southwark Crown Court on 7 January 2011 to 18 months in jail. His conviction is a sober reminder that privilege cannot be used to shield MPs from acts which stand in stark contrast to the very ideal it is meant to protect: the fostering of accountability and democratic governance through open debate.

YVONNE TEW

EXEMPLARY DAMAGES: "PUBLIC LAW" FUNCTIONS, MENS REA AND QUANTUM

IT is not uncommon to read that "[d]amages and compensatory remedies have not traditionally played a major role in British public law" (Turpin \& Tomkins, British Government and the Constitution, $6^{\text {th }}$ ed, (Cambridge 2007) p. 276). However, damages actions in tort have long served "public law" functions: protecting fundamental rights, controlling and delineating the bounds of governmental power, and giving effect to rule-of-law principles of equality, and government under law. As the recent case of Muuse v. Secretary of State for the Home Department [2010] EWCA Civ 453, [2010] W.L.R.(D) 108 demonstrates, exemplary damages are a significant aspect of this 